UDC 619:616.98

\title{
BASIC PRINCIPLES AND CONCEPTION SUPPORT OF VETERINARY STATE POLICY
}

N. MEZHENSKA, $\mathrm{PhD}$, associated professor

\section{National University of Life and Environmental Sciences of Ukraine}

E-mail: nataamezh@gmail.com

Abstract. Sanitary and phytosanitary measures(SPS)are concerned to specific risks that international trade creates for the health and life of humanity and animals and plant safety. Epidemiology (and epizootiology, as its component) plays a central role in the implementation of the WTO Agreement on Sanitary and Phytosanitary Measures (SPS). Thanks to theimplementation of this agreement, it is scientifically reasonable, adequate (equivalent), transparent, based on principles of regionalization and risk analysis.

Key words: epidemiology,risk analysis, regionalization, harmonization, transparency, equivalency

Historically, the diseases were spread across international borders through the movement of animals and food products of animal origin.

The outbreak of rinderpest in 1920 in Belgium caused a need for creationof international organization for the settlement of animal trade and products of animal origin.

Thus in January 25, 1924 in Paris, there was created the International Epizootic Office (OIE). Agreement concerning the establishment of the organization was signed with 28 countries. In May, 2003, the OIE was renamed to the World Organization for Animal Health, but has kept its historical abbreviation OIE.

After the end of the Second World War, there were started the negotiations on the establishment of the World Trade Organization (WTO), under the UN auspicesin the world. During the UN Conference in 1948 itwas adopted the Havana Charter, which approved the Statute of WTO. Had been however, the Havana Charter has not entered into thefactor because the parliaments of some countries, including the US, refused to ratify the Agreement on the Statute of WTO. 
In 1945 the United States proposed the creation of the International Trade Organization (ITO). And the development of the Statute of Charter ITO carried on the London (1946), Geneva (1947) and Havana conferences (1947 - 1948) [5].

The result was productive. For example, it was adopted 45 thousands of tariff discounts (equivalent to 10 billion dollars USA), which became the principal features of a liberalized market, the basis for the international tradein the future.

In 1947 these discounts were approved with the rules of the international trade and fixed in Chapter IV of the statute ITO, which was called "The General Agreement on Tariffs and Trade" and statute ITO - "Havana Charter" [5].

The Statute also contained the rules concerning regulations of restrictive trade practices, the use of international trade agreements as a form of stabilization of commodity markets, established the principle of the biggest contribution and the principle of non-discrimination in determining any prohibitions or restrictions in trade. The Statute was signed away over 50 countries in the world.

During the work on the Statute of WTO representatives of 23 countries have started to look for opportunities to reduce of protectionism in the international trade. It wasadopted 45,000 tariff discounts andthe rules of the international trade with the result of this work, which became known as the General Agreement on Tariffs and Trade (GATT).This agreement became effective from 1 January, 1948. Terms of GATT was not originally provided for the establishment of the international organization. Provisions of GATT were operating as an ordinary international agreement. Changes and additions to the rules could be realized within the framework of international conferences, which were called rounds. Due to introdution by of this agreement of the mechanism of tariff restrictions, the process of trade liberalization moved slowly, but surely.

The totals from 1946 to 1994 there were held eight rounds of multilateral trade negotiations within the GATT. The result of each round was the adoption of new agreements which governing various aspects of the international trade, in particular, reduce customs rates. 
The latest round of multilateral trade negotiations in the framework of complex of international agreements was the eighth GATT Uruguay round, which began in September 1986 in Punta Del Este (Uruguay). The adopted agenda was included issues that extend scope of international trade policy and the creation of a full-fledged international organization as it was.To the discussion it has been included the issue of regulation of trade in services and intellectual property rights for international investment. The most difficult sessions in the Uruguay Round negotiations was the question of access to the markets of agricultural products.

In April 1994, most of the participants of the negotiation process (123 out of 125 participants) in Marrakech (Morocco) signed the Final Act of the Uruguay Round of trade negotiations and the Marrakesh Declaration, which established the World Trade Organization. Negotiations within the GATT 1947 were completed. Nowdays, GATT 1994 as an agreement about trade in goods is one of major agreements in the WTO.It is complemented by the General Agreement on Trade in Services (GATS) and the Agreement on Trade-Related Aspects of Intellectual Property Rights (TRIPS), the Agreement on Sanitary and Phytosanitary Measures, (SPS). WTO launched its activity on 1 January, 1995.

The WTO Agreement about Sanitary and Phytosanitary Measures (SPS) also came into force since January 1, 1995. Grace period for its implementation expired on January 1, 1997.

The purpose of SPS agreement is was facilitating the trade in at the same time ensuring the safety of human health, animals and the planet.

Present situation of the international trade in animals and animal products requires that all sanitary and phytosanitary measures have scientific justification, at least restrictive, but so that they could achieve the desired, level of protection, with not discriminatory, permanent and not used in the case of artificial barriers to trade. This fact requires the strengthening of monitoring and develop of the ability to analyze risks for their respective evaluations and prevention the emergence of disease because of trade. 
The purpose of research. Todetermine the role of epidemiology (and epizootology as its component part) in maintenance of the implementation of WTO Agreement on Sanitary and Phytosanitary Measures (SPS).

Material and methods of research. In the process of work there was used data of analysis of Veterinary statistical reports and course materials of base of Veterinary Epidemiology and Risk Analysis of US Department of Agriculture (USDA), including the Epidemiology and Animal Health (SEAN), Inspectors service of protection of animals and plants (APHIS), veterinary services in cooperation with the center of the OIE of information systems, risk analysis and epidemiological modeling of animal diseases. It was used statistic-analytical method of analysis of documentary in thiswork.

Results. Epidemiology (and epizootology as its integral part) is the science about population interactions and effects that usually wouldn't appear in the individual and / or single observations, and are associated with data processing of array (populations) [1].

In world literature the relationship between the concepts of "epizootology" and "epidemiology" is clearly decided in favor of semantic but not etymological approach. In published under the auspices of the OIE reference book (Toma et al., 1999, p. 88-89) is given a definition of epizootology: "Epizootology is an archaic term, used in relation to the epidemiology of animal populations. The use of the term "epidemic" preferred term "epizootic" even in the context of animal diseases"[4].

Epidemiology functions as a diagnostic discipline at the population level and puts as its primary task to identify factors that affect on health of populations. Identifying these factors contribute to the problem solving, that allows pragmatically approach to the problem of protection and control for a particular disease, and in this part epidemiology is closely related with the economy and the social sciences [2].

The solution a number of problems of epidemiology / epizootology is carried out in cooperation and / or under the control of international organizations such as OIE, FAO (Food and Agriculture Organization), WTO, which requires from national 
experts not only knowledge of adopted abroad methodologies and professional languagebut also the use of them in practice.

The global program for the eradication of rinderpest, foot and mouth disease, on control over emergence infections require from modern veterinary experts using of widely recognized standard (harmonized with the international) techniques and methods for determining the sampling units, criteria for stratification and sample size for laboratory research and monitoring.

Under WTO rules, governments must apply sanitary and phytosanitary measures based on risk analysis to enable these measures were not used as barriers to trade (it must be serious and scientifically substantiated reason to apply the rules SPS) [6].

Risk isthe probability of emergence and the potential scale of the consequences of any event that could harm the health of the animal or human from biological or economic point of view [7].

Risk Analysisis a process that includes identification of hazards, risk assessment, risk management and reporting about the risk [7].

Epidemiology (epizootology) studies the reasons, dynamics and spread of the disease in the population. The risk of being infected by pathogenic factor, and accordingly, get sick is determined by characteristics of the agent (pathogen), condition of the host organism and the susceptibility of the population (accommodation on the territory, factors of resistance, congenital and acquired immunity).These risk factors, in their turn, are strongly influenced by behaviour of people and animals, the environment (including the social component) and the ecological condition of the region due to the fact, that they influence and sometimes determine the transmission and spread of pathogenic factor on the territory and from the one host to another.

So, epidemiology is apart of population biology and is trying to unite disparate facts together.

Taking away from describing character, epidemiology / epizootology introduced its quantitative methods to provide trends that characterize the disease (as 
contagious and non-contagious), has achieved significant progress in the understanding of causality and etiology of diseases and active measures for control the disease.

Epidemiology / epizootology proved its effectiveness in clarifying the role of harmful factors / agents in the etiology conventional, factorial and also diseases with mixed etiology; in recognizing of interaction of harmful factors with environmental factors (causal and associative interaction); factors that determine sensitivity of host (homeostasis, resistance, immunity, genetic predisposition); in creating intelligible (and not logically contradictory) models of transmission pathways and spread of diseases.Based on epidemiological knowledge are planned, financed and implemented measures to eliminate and control of diseases and all large-scale (field) evaluation of vaccines, diagnosticums and medicines.

Therefore risk analysis of animal healthcannot be held without the basic principles of epidemiology (epizootology), because this science provides the understanding of disease transmission, defines the ways of entry of the disease and the impact of measures to minimize the consequences.

Adequacy (equivalence)SPS measures allows the recognition that different SPS measures can achieve similar results. Therefore thanks to epidemiology (epizootology) are developed methods to compare the impact of measures to reduce the impact and also developed criteria for determining appropriate level of protection. It is necessary to focus on results, not on the approaches.

Transparencyduring realization of the WTO Agreement on Sanitary and Phytosanitary Measures (SPS) is countries must inform the WTO about the changes and ways of SPS measures, which can have a significant impact on trade and mandatory reporting about the disease, because the reporting about the disease is the basis of trust. A systemepid-/epiz- supervision is the basis for proper reporting about the disease.

Earlier, the occurrence of the event of sickness meant that the whole country was considered as it was affected. Regionalization and compartmentalization enable 
more rational, science-based approach to control of the disease, which is less hampered trade.

Regionalization (zoning)isa procedure for determining subpopulations of different animal health statuses based ongeographical criteria.

This procedure is based on international standards (OIE), namely Terrestrial Animal Health Code (OIE) defines the concept, and National law - regulates their use.

Zone is clearly limited portion of the country, animal subpopulation, which has health status (differ from status of a country) with the clear status of animal health because ofdisease against which are used supervisory measures, protection and biological security to international trade.

The WTO Agreement about Sanitary and Phytosanitary Measures (SPS) provides a framework for regionalization (zoning), and defines the following types of zones:

- free zone is an area where it is proved the absence of any disease;

- infected area is an area where the disease is diagnosed;

- protected (buffer) is an area, where it is established for the protection of health status of animals of prosperous country and zone that isolates its contacts with the animals ofcountry or zones with another status;

- containment zone (quarantine) is an area, where there are several infected farms and there are available epidemiological (epizootic) factors, it is conducted epidemiological (epizootic) investigation, accepted measures to prevent the spread of the pathogen in the prosperous country or area.

Compartmentalization isthe procedure for determining subpopulations of different animal health statuses based oncontrol and biosafety.

This procedure is also based on international standards (OIE), but the concept is developed by SEAN at the request of OIE Scientific Commission and published in the OIE analysis [6].

Compartment is theanimal subpopulation of one or more farms with a single biological safety management system, which has separate sanitary status of one or 
several diseases, against which are used for surveillance measures, prevention and bio-security in order to international trade.

\section{Conclusions}

1. The WTO Agreement on Sanitary and Phytosanitary Measures (SPS) has changed the principles and concepts of animal trade and animal products.

2. Epidemiology (and epizootology as its component parts) plays a central role in the implementation of the WTO Agreement on Sanitary and Phytosanitary Measures (SPS). Thanks to implementation of this agreement which is scientifically reasonable, adequate (equivalent), transparent, based on the principles of regionalization and risk analysis.

\section{References}

1. Dudnikov S. A. (2004). Kolichestvennaya ehpizootologiya: osnovy prikladnoj ehpidemiologii i biostatistiki [Quantitative epizootology: foundations of applied epidemiology and biostatistics]. OOO «Demiurg»: Vladimir, 460.

2. Materialy kursu bazovoiepidemiolohii ta analizu ryzykiv dlia pratsivnykiv ofitsiinykh veterynarnykh sluzhb (2011-2014 rr.). [Course materials of basic epidemiology and risk analysis for the official veterinary services workers].Kyiv, 1014.

3. Thrusfield M. (1995). Veterinary epidemiology.London: Blackwell Scienc, 483.

4. Toma B. (1999). Dictionary of veterinary epidemiology.Ames: Iowa UP, 284.

5. Chybisov D. M. (2011). Stanovlennia mizhnarodnoho ekonomichnoho pravoporiadku u 1945-1995 rokakh: istoryko-pravovyi analiz Heneralnoi uhody z taryfiv i torhivli 1947 roku [The establishment international economical law and order in 1945-1995: historic-legal analysis of General Agreement about tariff and trade 1947].Pivdennoukrainskyipravovyichasopys. 2, 215-218.

6. Informatsii na zamitka dlia zatsikavlenykh storin 5. Available at:http://www.ctaeconomic.com/5-SPS(Ukr).pdf

7. Kodeks zdorov'ya nazemnyhzh ivotnyh MEHB. Available at: https://www.fsvps.ru/fsvps-docs/ru/importExport/tsouz/docs/RU-VOL1a-2010.pdf.

8. Skott A. (2006).Koncepciya kompartmentalizacii [The conception of compartmentalisation]. OIE Scientific and Technical Review.25(3), 873-879. 


\section{БАЗОВІ ПРИНЦИПИ ТА КОНЦЕПЦІЯ ЗАБЕЗПЕЧЕННЯ ВЕТЕРИНАРНОЇ ПОЛІТИКИ ДЕРЖАВИ \\ Н. А. Меженська}

Анотація. Санітарні і фітосанітарні заходи(SPS) стосуються окремих ризиків, які створюе міжнародна торгівля для здоров'я $i$ життя людей та тварин і безпеки рослин.Епідеміологія (і епізоотологія, як їі складової частини) відіграють центральну роль в забезпеченні реалізації Угоди СОТ про застосування санітарних та фітосанітарних заходів (SPS). Завдяки чого виконання даної угоди є науково обтрунтованим, адекватним (еквівалентним), прозорим, базується на принципах регіоналізачії тааналізу ризиків.

Ключові слова:епідеміологія, аналіз ризику, регіоналізація, гармонізація, прозорість, еквівалентність.

\section{БАЗОВЫЕ ПРИНЦИПЫ И КОНЦЕПЦИЯ ОБЕСПЕЧЕНИЯ ВЕТЕРИНАРНОЙ ПОЛИТИКИ ГОСУДАРСТВА Н. А. Меженская}

Аннотация.Санитарные и фитосанитарные меры (SPS) касаются отдельных рисков, которые создает международная торговля для здоровья и жизни людей, животных и безопасности растений. Эпидемиология (и эпизоотология, как ее составная часть) играют чентральную роль в обеспечении реализации Соглашения ВТО о применении санитарных и фитосанитарных мер (SPS). Благодаря чему выполнения данного соглашения является научно обоснованным, адекватным (эквивалентным), прозрачным, базируется на принципах регионализачии и анализа рисков.

Ключевые слова: эпидемиология, анализ риска, регионализация, гармонизачия, прозрачность, эквивалентность. 